Carta ao Editor / Letter to Editor

\section{Identificação dos polimorfismos do gene XRCC1 em pacientes com anemia falciforme}

Identification of polymorphisms of the XRCC1
gene in patients with sickle cell disease

Polyanna M. Alves ${ }^{1}$

Renata Canalle ${ }^{2}$

Paulo R. J. Martins ${ }^{3}$

Lusânia M. G. Antunes ${ }^{4}$

${ }^{1}$ Pós-Graduanda da Disciplina de Genética do Depto. de Ciências Biológicas da Universidade Federal do Triângulo Mineiro. ${ }^{2}$ Doutora do Laboratório de Biologia Molecular do Depto. de Puericultura e Pediatria da Faculdade de Medicina de Ribeirão Preto da Universidade de São Paulo.

${ }^{3}$ Professor da Disciplina de Hematologia do Depto. de Clínica Médica da Universidade Federal do Triângulo Mineiro.

${ }^{4}$ Professora da Disciplina de Genética do Depto. de Ciências Biológicas da Universidade Federal do Triângulo Mineiro.

\section{Sr. Editor:}

A grande variabilidade clínica e das características hematológicas encontradas nos pacientes com anemia falciforme não só proporciona um desafio para a compreensão dos mecanismos envolvidos, mas também pode ser a chave para as estratégias de intervenção terapêutica. ${ }^{1}$ Para contribuir com a caracterização das diferenças genéticas responsáveis pela diversidade encontrada na anemia falciforme, vários polimorfismos têm sido estudados.

O polimorfismo no gene da MTHFR (metilenotetraidrofolato redutase) foi investigado em falcêmicos, associado ao aumento dos níveis séricos de homocisteína total, descrito como um fator de risco para o desenvolvimento de doenças cardiovasculares. ${ }^{2} \mathrm{O}$ polimorfismo no gene da $M P O$ (mieloperoxidase) parece ter um papel importante na susceptibilidade de infecção nos indivíduos com anemia falciforme, ${ }^{3}$ assim como os genes que codificam os receptores CCR2 e CCR5, envolvidos na migração de leucócitos para os tecidos inflamados, além dos polimorfismos do gene da enzima óxido nítrico sintase endotelial (NOS3), que não parece acentuar as manifestações clínicas da doença. ${ }^{4}$

O gene de reparo do DNA XRCC1 (X-Ray Repair Cross Complementing family) tem um papel importante no reparo das quebras de fita simples no DNA induzidas pela oxidação em células humanas. ${ }^{5}$ Não há dados na literatura sobre a aná- lise de polimorfismos do gene XRCC1 em pacientes com anemia falciforme, os quais apresentam maior susceptibilidade de oxidação da hemoglobina $S$, resultando em maior geração de espécies reativas de oxigênio, tornando-a mais sensível ao estresse oxidativo do que a hemoglobina normal. ${ }^{6}$ As deficiências na capacidade de reparo do DNA devido às mutações ou polimorfismos dos genes de reparo, incluindo o $X R C C 1$, podem levar à instabilidade genômica, a qual resulta nas síndromes de instabilidade cromossômica e aumento do risco de desenvolvimento de vários tipos de tumores. ${ }^{6}$

Esta investigação foi realizada para identificar a presença de dois polimorfismos no gene XRCC1, que resultam na substituição de aminoácidos nos códons 194 (Arg194Trp) e 399 (Arg399Gln). A casuística constou de amostras de sangue periférico obtidas de pacientes com anemia falciforme e doadores voluntários do Hemocentro Regional de UberabaMG, após consentimento informado. Todas as amostras foram amplificadas e analisadas pela técnica de PCR-RFLP, com a utilização da enzima de restrição $M s p I .^{7}$ Os primers utilizados foram: 194F: 5'-GCCCCGTCCCAGGTA-3'; 194R: 5'AGCCCCAAGACCCTTTCACT-3' e 399F: 5'-TTGTG CTTTC TCTGTGTCCA-3' e 399R: 5'-TCCTCCAGCCTTTTCTGATA3', amplificando os fragmentos de 491 e 615 pb, respectivamente. As condições de reação de PCR (25 $\mu \mathrm{l})$ foram: $100 \mathrm{ng}$ de cada primer para o códon 194; 150 ng de cada primer para o códon 399; 300 ng de DNA genômico; 200 M dNTPs; 2,5 $\mu$ l de tampão de PCR 10 x (20 mM Tris-HCl, 50 mM KCl, $\mathrm{pH}$ 8,4); 3,0 mM $\mathrm{MgCl}_{2}$ e $1 \mathrm{U}$ de Taq polimerase. O ciclo de amplificação consistiu de $94^{\circ} \mathrm{C}$ por quatro minutos, trinta ciclos de $94^{\circ} \mathrm{C}$ por trinta segundos, $65^{\circ} \mathrm{C}$ por um minuto e meio e $72^{\circ} \mathrm{C}$ por um minuto, seguidos de cinco minutos a $72^{\circ} \mathrm{C}$. Após a reação de amplificação, $20 \mu \mathrm{l}$ do produto de PCR foram digeridos com $15 \mathrm{U}$ da enzima $M s p I$, a $37^{\circ} \mathrm{C}$ por uma noite, e então analisados em gel de poliacrilamida a $10 \%$, submetidos a eletroforese a $140 \mathrm{~V}$ e corados com brometo de etídeo. O alelo selvagem Arg para o códon 194 é identificado pela presença da banda de $292 \mathrm{pb}$, enquanto o alelo polimórfico Trp é caracterizado pela presença da banda de 313 pb (indicando a ausência do sítio de restrição $M s p I$ ). Quanto ao polimorfismo no códon 399, os genótipos Arg/ Arg, Arg/Gln e Gln/Gln são identificados pelas bandas de 374/221, 615/374/221 e 615 pb, respectivamente.

A distribuição genotípica dos indivíduos falcêmicos e não falcêmicos para os códons 194 e 399 do gene XRCC1 está apresentada na Figura 1. Apenas um indivíduo falcêmico apresentou o genótipo heterozigoto no códon 194 (Arg/Trp), enquanto todos os outros indivíduos falcêmicos e não falcêmicos apresentam o genótipo homozigoto (Arg/Arg). Para o códon 399 do gene de reparo XRCC1, houve uma prevalência de indivíduos falcêmicos homozigotos (Arg/Arg) em relação ao número de indivíduos não falcêmicos para o mesmo genótipo. Por outro lado, obtiveram-se freqüências maiores do genótipo heterozigoto (Arg/Gln) nos indivíduos não falcêmicos (46,7\%) em comparação com os indivíduos falcêmicos (20,0\%), entretanto, não houve diferença estatística entre os resultados (Tabela 1).

O diagnóstico molecular dos polimorfismos genéticos 


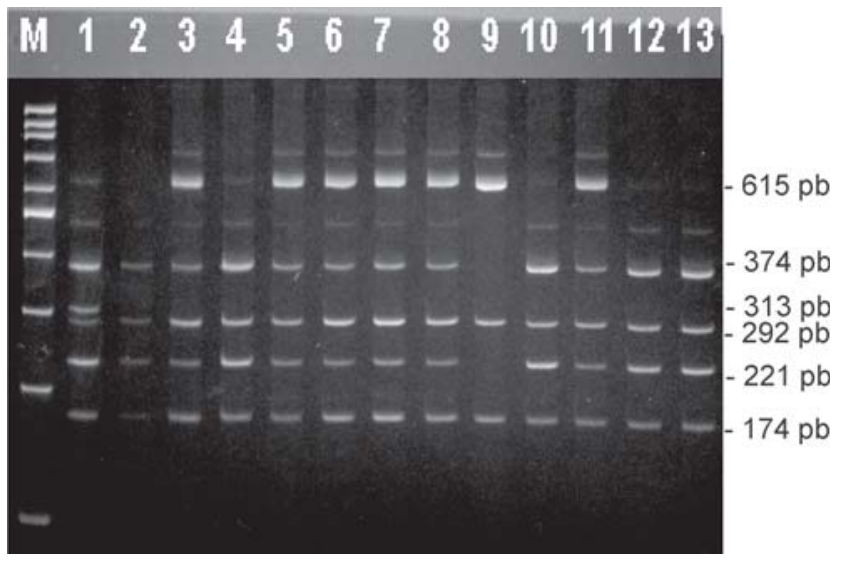

Figura 1. PCR-RFLP em gel de poliacrilamida $10 \%$ para detecção do polimorfismo XRCC1-Mspl, onde $\mathrm{M}=$ marcador de peso molecular (100 pb). Linha 1: heterozigoto para o códon 194 e homozigoto selvagem para o códon 399; Linhas 2, 4, 10, 12 e 13: homozigotos selvagens para ambos os códons; Linhas 3, 5-8 e 11: homozigotos selvagens para o códon 194 e heterozigotos para o códon 399; Linha 9: homozigoto selvagem para o códon 194 homozigoto polimórfico para o códon 399

Tabela 1

Distribuição das freqüências genotípicas e alélicas dos polimorfismos do gene $X R C C 1$ em indivíduos falcêmicos e não falcêmicos

\begin{tabular}{|c|c|c|c|c|c|}
\hline \multicolumn{6}{|c|}{ Número (\%) } \\
\hline Locus & Genótipo & Falcêmicos & $\begin{array}{c}\text { Não } \\
\text { Falcêmicos }\end{array}$ & OR (95\% IC) & $P$ \\
\hline \multirow{6}{*}{$\begin{array}{c}\text { XRCC1 } \\
194 \\
(\mathrm{C} / \mathrm{T}) \\
\mathrm{Mspl}\end{array}$} & Arg/Arg & $14 / 15(93,3)$ & $15 / 15(100,0)$ & 1,0 (referência) & \\
\hline & Arg/Trp & $1 / 15(6,7)$ & $0 / 15(0,0)$ & $0,31(0,01-8,3)$ & 1,00 \\
\hline & $\operatorname{Trp} / T r p$ & $0 / 15(0,0)$ & $0 / 15(0,0)$ & * & - * \\
\hline & Arg/Trp + Trp/Trp & $1 / 15(6,7)$ & $0 / 15(0,0)$ & $0,31(0,01-8,3)$ & $\overline{1,00}$ \\
\hline & Arg & 0,97 & 1,00 & - & \\
\hline & $\operatorname{Trp}$ & 0,03 & 0,00 & - & 1,00 \\
\hline \multirow{6}{*}{$\begin{array}{c}\text { XRCC1 } \\
399 \\
\text { (G/A) } \\
\text { Mspl }\end{array}$} & Arg/Arg & $10 / 15(66,7)$ & $7 / 15(46,7)$ & 1,0 (referência) & \\
\hline & Arg/GIn & $3 / 15(20,0)$ & $7 / 15(46,7)$ & $3,33(0,6-17,6)$ & 0,24 \\
\hline & $G / n / G I n$ & $2 / 15(13,3)$ & $1 / 15(6,7)$ & $0,71(0,5-9,5)$ & 1,00 \\
\hline & $A r g / G / n+G / n / G I n$ & $5 / 15(33,3)$ & $8 / 15(53,3)$ & $2,29(0,5-10,0)$ & 0,46 \\
\hline & Arg & 0,77 & 0,70 & - & \\
\hline & Gln & 0,23 & 0,30 & - & 0,77 \\
\hline
\end{tabular}

Arg/Arg = homozigoto para o alelo polimórfico; Arg/Trp e Arg/GIn = heterozigoto; Trp/Trp e G/n/Gln = homozigoto para o alelo polimórfico. OR = "odds ratio"; $I C=$ intervalo de confiança; $P=$ os valores foram calculados pelo teste de probabi-lidade exato de Fisher. *OR não calculada devido a número insuficiente.

poderia ser incluído como estratégia para a melhor compreensão da diversidade encontrada nos pacientes com anemia falciforme.

\section{Abstract}

Sickle cell disease (SCD) is an inherent disorder caused by a single nucleotide substitution. The great variability in clinical and hematological features of SCD provides a challenge in the understanding of the pathophysiological mechanisms leading to the disease. The identification of DNA polymorphisms can contribute to understand the role of the different biomarkers and their relationships with the extremely variable clinical manifestation of SCD. In order to contribute to the identification of polymorphisms in SCD, we proposed to study the distribution of the DNA repair gene XRCC1 in SCD patients and healthy control individuals. Our results indicate that the polymorphisms of the XRCC1 variant alleles 399GIn and 194Trp were not statistically different between the groups studied. We observed a tendency for the prevalence of the Gln/Gln genotype in SCD patients. The results from ongoing investigations with other polymorphisms have been elucidating the role of such biomarkers and their relationships with the clinical manifestation of SCD. Rev. bras. hematol. hemoter. 2006; 29(2): 198-199.

Key words: Polymorphisms; DNA repair; sickle cell; XRCC1.

\section{Referências Bibliográficas}

1. Weatherall MW, Higgs DR, Weiss H, et al. Phenotype/genotype relationships in sickle cell disease: a pilot twin study. Clin Lab Haematol. 2005;27:384-90.

2. Couto FD, Adôrno EV, Menezes JF, et al. C677T polymorphism of the MTHFR gene and variant hemoglobins: a study in newborns from Salvador, Bahia, Brazil. Cad Saúde Pública. 2004;20:529-33.

3. Costa RNP, Conran N, Albuquerque DM, et al. Association of the G463A myeloperoxidase polymorphism with infection in sickle cell anemia. Haematologica. 2005;90:977-9.

4. Vargas AE, da Silva MAL, Silla L, et al. Polymorphisms of chemokine receptors and eNOS in Brazilian patients with sickle cell disease. Tissue Antigens. 2005;66:683-90.

5. Brem R, Hall J. XRCC1 is required for DNA single-strand break repair in human cells. Nucleic Acids Res. 2005;33:2512-20.

6. Silva Filho IL, Gonçalves MS, Adôrno EV, et al. Triagem de hemoglobinopatias e avaliação da degeneração oxidativa da hemoglobina em trabalhadores portadores do traço falciforme (HbAS), expostos a riscos ocupacionais. Rev Bras Hematol Hemater. 2005;27:183-7.

7. Lunn MR, Langlois RG, Hsieh LL, et al. XRCC1 polymorphisms: effects on aflatoxin B1-DNA adducts and glycophorin A variant frequency. Cancer Res. 1999;59:2557-61.

Avaliação: Editor e dois revisores externos

Conflito de interesse: não declarado

Recebido: 25/05/06

Aceito: 21/06/06

Correspondência: Lusânia Maria Greggi Antunes

Depto. de Ciências Biológicas, Universidade Federal do Triângulo Mineiro

Rua Praça Manoel Terra 330 - Abadia

38025-050 - Uberaba-MG - Brasil

Tel: (34) 3318-5434 - Fax: (34) 3318-5462

E-mail: lusaantunes@yahoo.com.br 